\title{
Hydrogen peroxide and superoxide anion modulate pregnant human myometrial contractility
}

\author{
Averil Y Warren, Balwir Matharoo-Ball, Robert W Shaw and Raheela N Khan \\ Centre for Reproduction and Early Life, Institute of Clinical Research, University of Nottingham, \\ The Medical School, Derby DE22 3DT, UK
}

Correspondence should be addressed to R N Khan; Email: raheela.khan@nottingham.ac.uk

\begin{abstract}
Reactive oxygen species (ROS) have the propensity to cause macromolecular damage with consequent modification of cellular function. We investigated the effects of two particular oxidants, superoxide $\left(\mathrm{O}_{2}^{-}\right)$anions and hydrogen peroxide $\left(\mathrm{H}_{2} \mathrm{O}_{2}\right)$, on oxytocin-induced myometrial contractility using biopsies from women undergoing Caesarean section at term gestation. Isometric tension recordings were performed and concentration-response curves derived after addition of test agents. A maximal reduction in myometrial contractility to $27.2 \pm 4.5 \%$ of control was observed followed application of $\mathrm{H}_{2} \mathrm{O}_{2}$. The enzyme scavenger catalase (CAT) reduced the inhibitory effect of $\mathrm{H}_{2} \mathrm{O}_{2}$ but had little effect at 10-fold lower concentrations. Addition of dialysed xanthine oxidase \pm hypoxanthine significantly inhibited contractility to $23.8 .0 \pm 4.2 \%$ compared with control. Pre-incubation with superoxide dismutase and CAT diminished this effect. The non-specific potassium channel blocker, tetraethylammonium chloride $(1 \mathrm{mM})$, had no effect on myometrial contractility. We conclude that human myometrium is susceptible to the effects of ROS, which may be produced by reperfusion-ischaemic episodes during labour. Our findings could, in part, explain the weak or prolonged depression of contractions characteristic of myometrial dysfunction culminating in difficult labours.

Reproduction (2005) 130 539-544
\end{abstract}

\section{Introduction}

Untimely birth due to the premature onset of labour may be associated with an increased risk of perinatal death and long-term handicap (Goldenberg 2002, Slattery \& Morrison 2002). At the other extreme, poor progress in labour is a key factor for delivery by emergency Caesarean section. Parturition and infection-induced preterm labour resemble inflammatory processes (Gibbs et al. 1992, Hunt 1994, Thomson et al. 1999) that are linked to the production of reactive oxygen species (ROS) including superoxide $\left(\mathrm{O}_{2}^{-}\right)$, hydrogen peroxide $\left(\mathrm{H}_{2} \mathrm{O}_{2}\right)$ and peroxynitrite. ROS may also form during intermittent ischaemia induced by powerful myometrial contractions restricting blood flow to the uterus causing a reperfusion/ischaemia injury (Nakai et al. 2000). Zyrianov et al. (2003) have also shown increased free radical generation in human myometrium during labour. Moreover, raised serum and placental levels of lipid hydroperoxides have been demonstrated during the progression of normal pregnancy (Little \& Gladen 1999).

The response of the uterus to hypoxia is well-documented (Wray 1993, Taggart \& Wray 1995). Metabolic inhibition, using cyanide to mimic hypoxia, causes a reduction in the force of uterine contractions which is accompanied both in vivo (Larcombe-McDouall et al. 1998) and in vitro by intracellular acidification, decreased levels of ATP, phosphocreatine, intracellular $\mathrm{Ca}^{2+}$ $\left(\left[\mathrm{Ca}^{2+}\right]_{\mathrm{i}}\right)$ and increased inorganic phosphate levels (Wray 1990, Taggart \& Wray 1998). These findings have implications for dysfunctional labours and may be associated with the increasing numbers of 'failure of labour to progress' cases of which at least one in five births occurs by Caesarean section. In vascular, intestinal and airway smooth muscle, ROS have been found to affect contraction (Bauer et al. 1999, Callahan et al. 2001, Kimura et al. 2002) and contribute to muscle fatigue in skeletal muscle, although the mechanisms involved are incompletely understood. It has also been demonstrated that $\mathrm{O}_{2}^{-}$anion production increases $\left[\mathrm{Ca}^{2+}\right]_{i}$ in human myometrium, an effect that was abolished in the presence of the antioxidant enzymes superoxide dismutase (SOD) and catalase (CAT) (Masumoto et al. 1990).

Large conductance calcium-activated potassium channels $\left(\mathrm{BK}_{\mathrm{Ca}}\right)$ are ubiquitously distributed in smooth muscle, and have been demonstrated to play an important role in regulation of myometrial contractility (Trittart et al. 1991, 
Anwer et al. 1993, Khan et al. 1993) by a negative feedback mechanism to limit depolarization and contraction. Activation of $\mathrm{BK}_{\mathrm{Ca}}$ channels leads to membrane hyperpolarization, which closes voltage-dependent $\mathrm{Ca}^{2+}$ channels and reduces $\mathrm{Ca}^{2+}$ influx, resulting in a reduction in $\left[\mathrm{Ca}^{2+}\right]_{i}$ and hence relaxation.

There is increasing evidence that many cellular effects of ROS are mediated by changes in ionic conductance (Kourie 1998). DiChiara \& Reinhart (1997) demonstrated that oxidation with $\mathrm{H}_{2} \mathrm{O}_{2}$ leads to decreased $\mathrm{BK}_{\mathrm{Ca}}$ channel activity in HEK 293 cells transfected with the brain hslo $\alpha-$ subunit which encodes the BKCa channel. Conversely, $\mathrm{H}_{2} \mathrm{O}_{2}$ increases $\mathrm{BK}_{\mathrm{Ca}}$ channel activity to cause relaxation of porcine coronary artery (Barlow et al. 2000).

In view of the reported effects of ROS on the $\mathrm{BK}_{\mathrm{Ca}}$ channel and the fact that this channel is highly expressed in pregnant human myometrium, we hypothesized (i) that ROS modulate human myometrial contractility, and (ii) that this may occur via mechanisms that involve $\mathrm{BK}_{\mathrm{Ca}}$ channels. The following study was undertaken to test these hypotheses.

\section{Materials and Methods}

Myometrial samples were collected from women undergoing elective non-labour Caesarean section (38-41 weeks gestation) for previous Caesarean delivery, breech presentation or maternal request. Ethical approval was granted by the Southern Derbyshire Ethics Committee and written informed consent was obtained from all patients. Myometrial biopsies were taken from the upper section of the lower segment uterine incision and placed immediately in cold physiological salt solution (PSS) for transport to the laboratory. Samples were stored at $4{ }^{\circ} \mathrm{C}$ and used within $12 \mathrm{~h}$ of collection.

Myometrial samples were dissected free from serosal and decidual tissue and cut into eight longitudinal strips $(2 \times 2 \times 10 \mathrm{~mm})$. Each strip was mounted by means of a stainless steel hook and thread in $10 \mathrm{ml}$ PSS in an organ bath constantly bubbled with a $5 \% \mathrm{CO}_{2} / 95 \% \mathrm{O}_{2}$ gas mixture at $37^{\circ} \mathrm{C}$. A passive tension of $2 \mathrm{~g}$ was applied to each strip before stimulation with $0.5 \mathrm{nM}$ oxytocin to induce myometrial contractions. Myometrial strips were allowed to equilibrate until stable contractions were observed (approximately 90-120 min) after which the following experiments were performed.

\section{Effect of $\mathrm{H}_{2} \mathrm{O}_{2}$}

$\mathrm{H}_{2} \mathrm{O}_{2}(1 \mu \mathrm{M}-100 \mathrm{mM})$ was added to the contracting strips in a cumulative dose-dependent manner every 25 min with or without pre-incubation with the non-specific $\mathrm{BK}_{\mathrm{Ca}}$ channel blocker tetraethylammomium chloride (TEA; $1 \mathrm{mM}$ ) or CAT (10 or $100 \mu \mathrm{g} / \mathrm{ml})$.

\section{Effect of the $\mathrm{O}_{2}^{-}$anion}

$\mathrm{O}_{2}^{-}$anion was generated by the reaction of xanthine oxidase $(\mathrm{XO})$ with hypoxanthine $(\mathrm{HX})$. XO was introduced to the baths $5 \mathrm{~min}$ before the addition of $\mathrm{HX}(0.1$ or $1 \mathrm{mM})$. No significant difference was apparent when using either $\mathrm{HX}$ concentration, hence subsequent experiments were carried out with $0.1 \mathrm{mM} \mathrm{HX}$. The $\mathrm{HX} / \mathrm{XO}$ were added at $25 \mathrm{~min}$ intervals. Cumulative concentration-response curves with $\mathrm{XO}$ were carried out using two concentration ranges: a low range $(0,1,2,5,10$ and $20 \mathrm{mU} / \mathrm{ml})$ and a high range $(0,10,20,40,60,80$ and $100 \mathrm{mU} / \mathrm{ml})$, while $\mathrm{HX}$ was fixed at $0.1 \mathrm{mM}$. Due to the observed non-specific effects of using a non-dialysed XO preparation, experiments were repeated with the same concentrations of $\mathrm{HX} / \mathrm{XO}$ after dialysing $\mathrm{XO}$ and carrier against large volumes of PSS overnight at $4{ }^{\circ} \mathrm{C}$. Since the enzyme $\mathrm{XO}$ was manufactured as a suspension in ammonium sulphate $(2.3 \mathrm{M})$ and sodium salicylate $(1 \mathrm{mM})$, contractile responses were also recorded with the corresponding concentrations of these molecules, without $\mathrm{XO}$, to assess nonspecific effects. In order to establish the specificity of ROS action, experiments were carried out by pre-incubating myometrial strips with the antioxidative enzyme SOD (10 or 100 units $/ \mathrm{ml}$ ) or CAT (100 or $1000 \mu \mathrm{g} / \mathrm{ml}$ ) for $30 \mathrm{~min}$ in order to quench the production of $\mathrm{O}_{2}^{-}$anion and $\mathrm{H}_{2} \mathrm{O}_{2}$ respectively.

\section{Data acquisition and analysis}

Changes in isometric tension, detected by mechanical displacement of force transducers (AD Instruments, Oxford, UK) were digitized and the data collected using the PowerLab system with Chart 4.1 software (AD Instruments). Control contractile responses (\% maximal contractility) were calculated from oxytocin-induced contractility data obtained over a 20 min period before addition of test agents. Data for each series of experiments were analysed by the calculation of activity integrals expressed as a function of \% maximal contractility at each concentration of drug used. The resulting dose-response curves were compared using Prism 4 software (GraphPad, San Diego, CA, USA). Paired Student's $t$-test or one-way ANOVA was used to assess variability between means. A $P$ value $<0.05$ was regarded as statistically significant. Results are reported as means \pm S.E.M. for $n$ observations.

\section{Drugs and solutions}

Oxytocin, XO, HX, SOD, CAT, TEA and $\mathrm{H}_{2} \mathrm{O}_{2}$ were all purchased from Sigma-Aldrich Co., Ltd. Where applicable all drugs were prepared as stock solutions in PSS and stored frozen $\left(-20^{\circ} \mathrm{C}\right)$ until the day of use. The composition of the PSS used in all experiments was as follows:$(\mathrm{mM}) \mathrm{NaCl} 119, \mathrm{CaCl}_{2} \cdot 2 \mathrm{H}_{2} \mathrm{O} 1.6, \mathrm{NaHCO}_{3} 25, \mathrm{KCl} 4.7$, $\mathrm{KH}_{2} \mathrm{PO}_{4} 1.18, \mathrm{MgSO}_{4} \cdot 7 \mathrm{H}_{2} \mathrm{O} 1.17$, glucose $5.5(\mathrm{pH} 7.4$ when gassed with $5 \% \mathrm{CO}_{2} / 95 \% \mathrm{O}_{2}$ ). 


\section{Results}

Myometrial strips mounted for isometric tension recordings exhibited rhythmic, reproducible contractions to stimulation with $0.5 \mathrm{nM}$ oxytocin. Control experiments (with no additional application of drugs) showed little change in either magnitude or frequency of contractions for the duration of the experiment (data not shown).

\section{Effect of $\mathrm{H}_{2} \mathrm{O}_{2}$}

Application of $\mathrm{H}_{2} \mathrm{O}_{2}\left(10^{-6}-10^{-1} \mathrm{M}\right)$ produced a concentration-dependent relaxation of myometrial strips stimulated with oxytocin (Fig. 1, upper panel). A maximal decrease in contractility to $27.2 \pm 4.5 \%(n=7)$ with $100 \mathrm{mM} \mathrm{H}_{2} \mathrm{O}_{2}$ compared with control activity was noted $(P<0.001$; Fig. 2. Pretreatment of tissue with the free-radical scavenger CAT at $1000 \mu \mathrm{g} / \mathrm{ml}$ partially inhibited the relaxation produced by $\mathrm{H}_{2} \mathrm{O}_{2}$ (Fig. 1, lower panel) to a maximum reduction in force of $57.3 \pm 7.8 \%$ of control activity $(n=7)$. This effect achieved significance at concentrations of $10^{-4} \mathrm{M}$ and above $(P<0.05$; Fig 2$)$. Incubation of tissue strips with lower concentrations of CAT $(100 \mu \mathrm{g} / \mathrm{ml})$ had no significant effect on contractility $(n=5 ; P>0.05)$. Pretreatment of tissues with the $\mathrm{BK}_{\mathrm{Ca}}$ channel blocker, TEA at a concentration of $1 \mathrm{mM}$ did not affect $\mathrm{H}_{2} \mathrm{O}_{2}$-mediated relaxation.

\section{Effect of the $\mathrm{O}_{2}^{-}$anion}

Cumulative addition of non-dialysed XO (0-100 mU) and $0.1 \mathrm{mM} \mathrm{HX}$ to produce $\mathrm{O}_{2}^{-}$anion, caused a significant dose-dependent decrease in contractility of the myometrial strips (data not shown). This prompted us to perform experiments to investigate the effects of the carriers, ammonium sulphate and sodium salicylate, that formed the XO suspension, the outcomes of which demonstrated a significant effect of carrier molecules on myometrial activity. Hence, experiments were repeated with $\mathrm{XO}$ that had been dialysed against PSS. The results show that

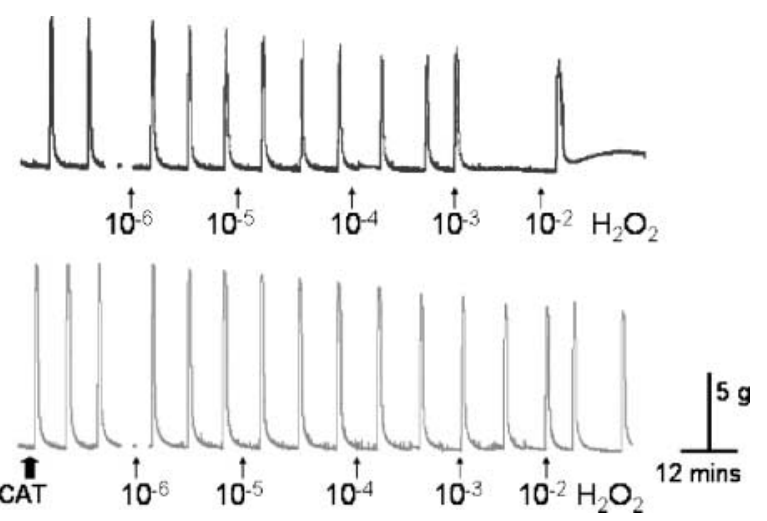

Figure 1 Upper panel: application of $\mathrm{H}_{2} \mathrm{O}_{2}\left(10^{-6}-10^{-2} \mathrm{M}\right)$ reduced maximal contractility of the human myometrium in a dose-dependent manner. Lower panel: pre-incubation with $1000 \mu \mathrm{g} / \mathrm{ml}$ CAT before addition of $\mathrm{H}_{2} \mathrm{O}_{2}$ prevented the relaxant action of $\mathrm{H}_{2} \mathrm{O}_{2}$.

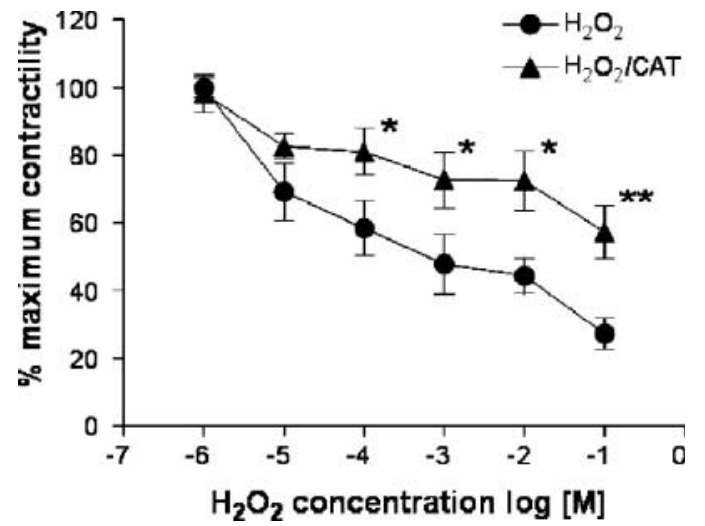

Figure 2 Application of $\mathrm{H}_{2} \mathrm{O}_{2}(\bigcirc)$ reduced maximal contractility of the human myometrium in a dose-dependent manner. Pre-incubation with $1000 \mu \mathrm{g} / \mathrm{ml}$ CAT $(\boldsymbol{\Lambda})$ before addition of $\mathrm{H}_{2} \mathrm{O}_{2}$ reduced the relaxant effect of the latter. Means \pm S.E.M. $* P<0.05 ; * * P<0.01 . n=7$.

HX/XO dose-dependently reduced myometrial contractility. Figure 3 illustrates a representative trace showing the effect of SOD/CAT pretreatment on subsequent $\mathrm{HX} / \mathrm{XO}$ addition. A maximal reduction to $23.8 \pm 4.2 \%$ of control ( $n=8 ; P<0.001 ;$ Fig. 4) at the highest concentration of XO tested $(100 \mathrm{mU} / \mathrm{ml})$, while $\mathrm{HX}$ was held constant at $0.1 \mathrm{mM}$. Addition of SOD (100 units $/ \mathrm{ml})$ and CAT $(100 \mu \mathrm{g} / \mathrm{ml})$ to the bath caused a significant reduction in the ability of $\mathrm{HX} / \mathrm{XO}$ to relax myometrial strips with a $62.2 \pm 6.5 \%$ inhibition in force compared with control activity ( $n=8 ; P<0.05$; Fig. 4$)$.

In preliminary experiments, we observed that a single application of $\mathrm{XO} / \mathrm{HX}$ was sufficient to fully inhibit myometrial contractility over $1 \mathrm{~h}$. This phenomenon was examined further by testing the effect of a single dose of $100 \mathrm{mU} \mathrm{XO} / 0.1 \mathrm{mM} \mathrm{HX}$ (undialysed and dialysed) on frequency of myometrial contractions. Addition of undialysed $100 \mathrm{mU} \mathrm{XO} / 0.1 \mathrm{mM} \mathrm{HX}$ abolished contractions by $1 \mathrm{~h}(n=4 ; P>0.05)$ compared with control strips (data not shown). However, dialysed $\mathrm{HX} / \mathrm{XO}$ had no significant

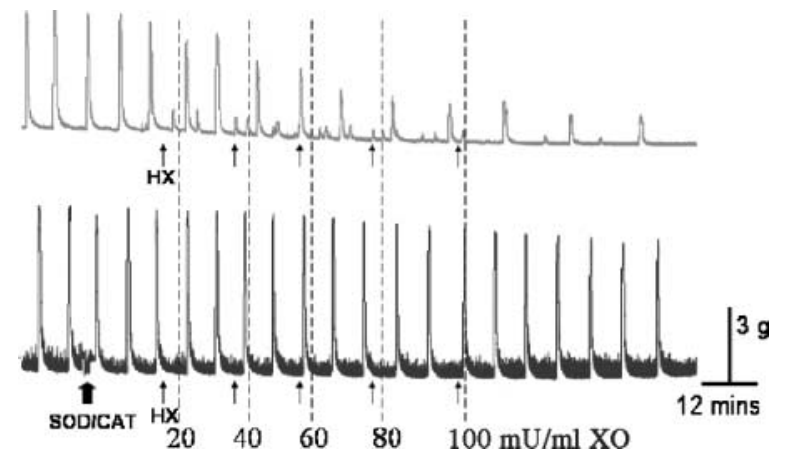

Figure 3 Upper panel: application of $\mathrm{HX} / \mathrm{XO}$ reduced contractility of the human myometrium in a concentration-dependent manner. Small arrows indicate addition of $0.1 \mathrm{mM} \mathrm{HX} 5$ min before incremental increases in $\mathrm{XO}$ (dashed lines). Lower panel: pre-incubation with $1000 \mu \mathrm{g} / \mathrm{ml}$ CAT and $100 \mathrm{units} / \mathrm{ml} \mathrm{SOD}$ before addition of HX/XO prevented the relaxant effect of $\mathrm{H}_{2} \mathrm{O}_{2}$. 


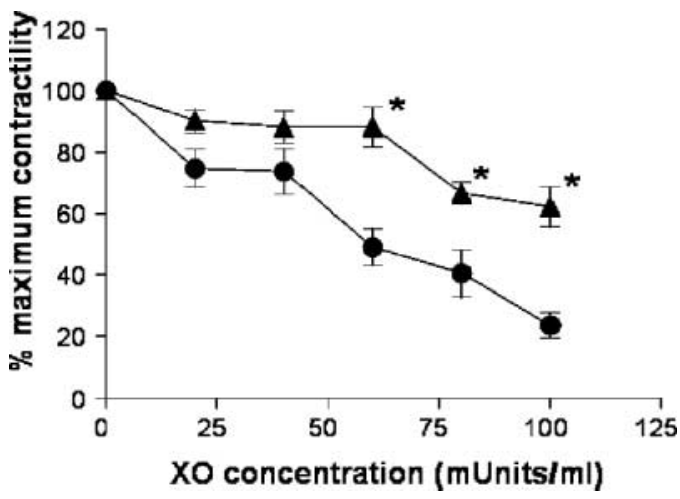

Figure 4 The effect of $\mathrm{HX} / \mathrm{XO}\left(\mathrm{O}_{2}^{-}\right.$-generating system) on oxytocininduced myometrial contractility. The graph depicts the decrease in myometrial contractility due to the effects of $\mathrm{HX} / \mathrm{XO}(\bullet)$. Pre-incubation with SOD/CAT before HX/XO (ム) reduced inhibition compared with $\mathrm{H}_{2} \mathrm{O}_{2}$ alone. Means \pm S.E.M. $* P<0.05 . n=8$.

effect on $\%$ frequency compared with controls $(n=5$; $P>0.05$.

Dialysed carrier alone or in the presence of SOD/CAT had no significant effect on myometrial contractility, reducing it respectively to $84.1 \pm 6.8$ and $78.6 \pm 3.8 \%$ of control over a $3 \mathrm{~h}$ recording period $(n=6 ; P>0.05$; Fig. $5)$. Nor was this effect significantly different from that with PSS replacing dialysed carrier solution (Fig. 5).

\section{Discussion}

Spontaneous vaginal delivery requires strong, coordinated contractions of the uterus to propel the fetus through the birth canal. In some cases, contractions may cause compression of blood vessels supplying the uterus. The episodic nature of this process is likely to trigger a chain of reperfusion-ischaemia events which result in the generation of ROS. Indeed, the human myometrium produces ROS, levels of which are elevated during labour (Zyrianov et al. 2003). In addition, the human myometrium is endowed with enzymatic scavenging systems (SOD, CAT,

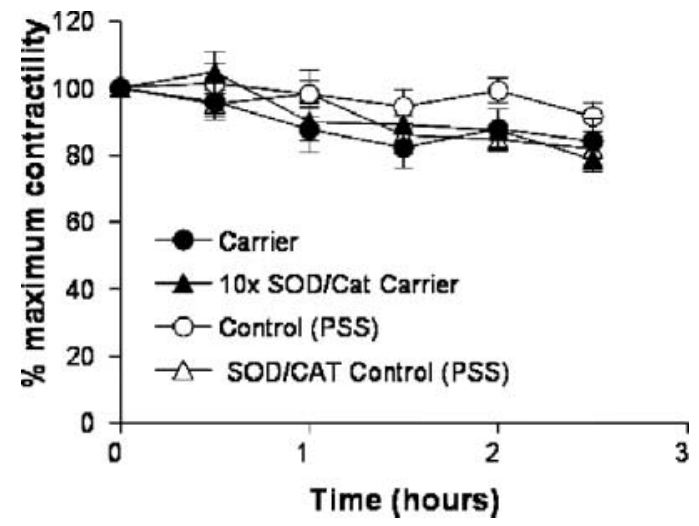

Figure 5 The effect of dialysed carrier $(\bullet)$, carrier + SOD/CAT ( $(\mathbf{\Lambda})$, PSS alone $(O)$ and PSS + SOD/CAT $(\triangle)$ on contractility with time. There was no significant difference between any of the treatments. $n=4$.

Reproduction (2005) 130 539-544 glutathione peroxidase) that minimize the potentially destructive effects of ROS (Telfher et al. 1997, MatharooBall \& Khan 2003).

In this study we have explored the hypothesis that ROS modify the contractility of the human myometrium and that this may contribute to the disruption of regular coordinated myometrial contractions during the process of labour. To the best of our knowledge this is the first study to examine the direct effects of $\mathrm{O}_{2}^{-}$anion and $\mathrm{H}_{2} \mathrm{O}_{2}$ on the contractile properties of human myometrium. Our results provide evidence that $\mathrm{H}_{2} \mathrm{O}_{2}$ caused a diminution in contractions of non-labour human myometrium, which was considerably reduced after addition of CAT. Paradoxically, Cherouny et al. (1989) using pregnant rat myometrial segments illustrated that $\mathrm{H}_{2} \mathrm{O}_{2}$ enhanced contractility and that this effect occurred concomitantly with increased prostaglandin- $\mathrm{F}_{2} \alpha$ and $-\mathrm{E}_{2}$ release. The disparity between our study and that of Cherouny et al. (1989) could be explained by species differences in the control of myometrial function, gestation and parturition.

There is mounting evidence that $\mathrm{H}_{2} \mathrm{O}_{2}$ may exert its effects through many cellular targets that include membrane ion channels. Raised $\left[\mathrm{Ca}^{2+}\right]_{\mathrm{i}}$ levels triggering cell death have been linked to $\mathrm{H}_{2} \mathrm{O}_{2}$ acting on a non-selective cation channel in rat CRI-G1 cells (Herson et al. 1999). However, elevated $\left[\mathrm{Ca}^{2+}\right]_{i}$ levels, elicited by $\mathrm{H}_{2} \mathrm{O}_{2}$, may also activate $\mathrm{BK}_{\mathrm{Ca}}$ channels to promote relaxation as shown in canine trachealis (Janssen et al. 2000). BK $\mathrm{Ca}$ channels are expressed at high density in myometrial cells and are important effector molecules that mediate relaxation. Our observation that pretreatment of myometrial strips with $1 \mathrm{mM}$ TEA, an extracellular concentration that specifically blocks $\mathrm{BK}_{\mathrm{Ca}}$ channels (Khan et al. 1993), did not overcome the $\mathrm{H}_{2} \mathrm{O}_{2}$-induced relaxation hints at the involvement of other mechanisms. In canine trachealis, relaxations triggered by $\mathrm{H}_{2} \mathrm{O}_{2}$ and $\mathrm{OH}^{\bullet}$ are thought to act via several different ion channel subtypes (Janssen et al. 2000). It is possible therefore, that the $\mathrm{H}_{2} \mathrm{O}_{2}$ effects uncovered in our study may similarly involve more than one particular ROS acting to modify uterine function.

Experimental hypoxia is linked to a reduction in the force of myometrial contractions but it is far from clear how and why uterine contractions wane during some labours. While undoubtedly due in part to the excessive energy demands of the uterus to support labour as well as the power of the contractions, we hypothesized that cellular damage to contractile elements, due to ROS activity at muscle cells, would interfere with this cascade. Our own observations suggest that short hypoxic insults reversibly reduce the contractile force of human myometrial strips. However, longer exposure to hypoxia (>40 min) resulted in abolition of myometrial contractions ( $\mathrm{Y}$ Y Warren \& R $\mathrm{N}$ Khan, unpublished observations) consistent with our data revealing a decrease in uterine contractility with $\mathrm{O}_{2}^{-}$ anion. This finding is also in agreement with a number of studies reporting altered contractile properties in canine trachealis (Janssen et al. 2000), guinea-pig trachea (Matyas 
et al. 2002) and rat diaphragm (Callahan et al. 2001) smooth muscle. It is significant that the relaxation produced by $\mathrm{O}_{2}^{-}$anion with dialysed $\mathrm{XO}$ was much less than that evident using non-dialysed $\mathrm{XO}$ and emphasized the importance of proper controls. In contrast, Masumoto et al. (1990) reported $\mathrm{O}_{2}^{-}$induced increases in $\left[\mathrm{Ca}^{2+}\right]_{l}$ in human myometrium. They postulated that this would translate to enhanced myometrial contractility. However, these opposing observations may be explained by the different techniques employed in the two studies where Masumoto et al. (1990) used digital microscopy to evaluate the changes in $\left[\mathrm{Ca}^{2+}\right]_{i}$ concentrations while the present study investigated the effects of $\mathrm{HX} / \mathrm{XO}$ directly on myometrial contractions. Masumoto et al. (1990) also utilized enzymatically dispersed cells, hence it is difficult to simply extend these findings to tissue strips that are likely to have intact signalling pathways. It is also feasible that endogenous $\mathrm{O}_{2}^{-}$dismutates spontaneously to $\mathrm{H}_{2} \mathrm{O}_{2}$. Unlike impermeant $\mathrm{O}_{2}^{-}$anion, $\mathrm{H}_{2} \mathrm{O}_{2}$ crosses biological membranes with relative ease, which may mean that the actions of $\mathrm{H}_{2} \mathrm{O}_{2}$ on isolated cells are probably more rapid. This would lend support to our finding that both $\mathrm{H}_{2} \mathrm{O}_{2}$ and $\mathrm{O}_{2}^{-}$impair myometrial function. The lack of effect of SOD/CAT to contracting tissue strips without $\mathrm{HX} / \mathrm{XO}$ suggests that the antioxidative capacity in our myometrial preparations is highly effective at removing ROS. This is supported by our findings that human myometrium expresses high levels of $\mathrm{Cu} / \mathrm{Zn}-\mathrm{SOD}$ and CAT (Matharoo-Ball \& Khan 2003).

When ROS production exceeds the scavenging capacity of myometrial antioxidant defences, oxidative stress may arise with consequent cellular dysfunction and tissue damage. The severity of muscle fatigue during prolonged labour is exacerbated by the actions of ROS. One of the deleterious outcomes of ROS damage, lipid peroxidation, results in altered membrane fluidity and local membrane disruption of the lipid bilayer that may perturb native signalling networks, thereby adversely affecting muscle function. An improved understanding of the physiological pathways that modulate ROS-mediated effects on uterine contractility will help define the complex processes that underlie parturition (term and preterm). This may lead to new scientific approaches to manage dysfunctional labours, possibly by limiting ROS production through stimulation of enzymatic or non-enzymatic antioxidative pathways.

In conclusion, the effects of $\mathrm{H}_{2} \mathrm{O}_{2}$ and $\mathrm{O}_{2}^{-}$anion on myometrial contractility highlight the complex interactions that exist between ROS signalling and control of muscle function in the pregnant human myometrium. Deciphering the pathways through which these oxidants operate may raise novel therapeutic opportunities in obstetrics.

\section{Acknowledgements}

Our thanks to clinicians, midwives, theatre staff and of course the patients at Derby City General Hospital for making this study possible. We are grateful to NHS Trent for financial support. The authors declare that there is no conflict of interest that would prejudice the impartiality of this scientific work.

\section{References}

Anwer K, Oberti C, Perez GJ, Perez-Reyes N, McDougall JK, Monga $\mathbf{M}$ et al. 1993 Calcium-activated $\mathrm{K}^{+}$channels as modulators of human myometrial contractile activity. American Journal of Physiology 265 C976-C979.

Bauer V, Sotnikova R, Machova J, Matyas S, Pucovsky V \& Stefek M 1999 Reactive oxygen species induced smooth muscle responses in the intestine, vessels and airways and the effect of antioxidants. Life Sciences 65 1909-1917.

Barlow RS, El-Mowafy AM \& White RE $2000 \mathrm{H}_{2} \mathrm{O}_{2}$ opens $B K_{C a}$ channels via the $\mathrm{PLA}_{2}$-arachidonic acid signaling cascade in coronary artery smooth muscle. American Journal of Physiology $\mathbf{2 7 9}$ $\mathrm{H} 475-\mathrm{H} 483$.

Callahan LA, She ZW \& Nosek TM 2001 Superoxide, hydroxyl radical, and hydrogen peroxide effects on single-diaphragm fiber contractile apparatus. Journal of Applied Physiology 90 45-54.

Cherouny PH, Ghodgaonkar RB, Gurtner GH \& Dubin NH 1989 The effect of the antioxidant, butylated hydroxy anisole, on peroxide-induced and spontaneous activity of the uterus from the pregnant rat. Biology of Reproduction 41 98-103.

DiChiara TJ \& Reinhart PH 1997 Redox modulation of hslo $\mathrm{Ca}^{2+}$ activated $\mathrm{K}^{+}$channels. Journal of Neuroscience 17 4942-4955.

Gibbs RS, Romero R, Hillier SL, Eschenbach DA \& Sweet RL 1992 A review of premature birth and subclinical infection. American Journal of Obstetrics and Gynecology 166 1515-1528.

Goldenberg RL 2002 The management of preterm labor. Obstetrics and Gynecology 100 1020-1037.

Herson PS, Lee K, Pinnock RD, Hughes J \& Ashford MLJ 1999 Hydrogen peroxide induces intracellular calcium overload by activation of a non-selective cation channel in an insulin-secreting cell line. Journal of Biological Chemistry 274 833-841.

Hunt JS 1994 Immunologically relevant cells in the uterus. Biology of Reproduction 50 461-466.

Janssen LJ, Netherton SJ \& Walters DK $2000 \mathrm{Ca}^{2+}$-dependent $\mathrm{K}^{+}$ channels and $\mathrm{Na}^{+}-\mathrm{K}^{+}$-ATPase mediate $\mathrm{H}_{2} \mathrm{O}_{2}$ - and superoxideinduced relaxations in canine trachealis. Journal of Applied Physiology 88 745-752.

Khan RN, Smith SK, Morrison JJ \& Ashford MLJ 1993 Properties of large conductance potassium channels in human myometrium during pregnancy and labour. Proceedings of the Royal Society London Series B 251 9-13.

Kimura C, Cheng W, Hisadome K, Wang YP, Koyama T, Karashima Y et al. 2002 Superoxide anion impairs contractility in cultured aortic smooth muscle cells. American Journal of Physiology 283 $\mathrm{H} 382-\mathrm{H} 390$.

Kourie JI 1998 Interaction of reactive oxygen species with ion transport mechanisms. American Journal of Physiology 274 C1-C24.

Larcombe-McDouall JB, Harrison N \& Wray S 1998 The in vivo relationship between blood flow, contractions, $\mathrm{pH}$ and metabolites in the rat uterus. Pflugers Archiv 435 810-817.

Little RE \& Gladen B 1999 levels of lipid peroxides in uncomplicated pregnancy. Reproductive Toxicology 13 347-352.

Masumoto N, Tasaka K, Miyake A \& Tanizawa O 1990 Superoxide anion increases intracellular free calcium in human myometrial cells. Journal of Biological Chemistry $26522533-22536$.

Matharoo-Ball B \& Khan RN 2003 Antioxidative enzyme expression and lipid peroxidation in human myometrium with parturition. Proceedings of the Physiological Society 552P C10.

Matyas S, Pukovsky V \& Bauer V 2002 Effects of various reactive oxygen species on the guinea pig trachea and its epithelium. Japanese Journal of Pharmacology 88 270-278. 
Nakai A, Oya A, Kobe H, Asakura H, Yokota A, Koshino et al. 2000 Changes in maternal lipid peroxidation levels and antioxidant enzymatic activities before and after delivery. Journal of Nippon Medical School 67 434-439.

Slattery MM \& Morrison JJ 2002 Preterm delivery. Lancet 360 1489-1497.

Taggart MJ \& Wray S 1995 The effect of metabolic inhibition on rat uterine intracellular $\mathrm{pH}$ and its role in contractile failure. Pflugers Archiv 430 125-131.

Taggart MJ \& Wray S 1998 Hypoxia and smooth muscle function: key regulatory events during metabolic stress. Journal of Physiology 509 305-315.

Telfer JF, Thomson AJ, Cameron IT, Greer IA \& Norman JE 1997 Expression of superoxide dismutase and xanthine oxidase in myometrium, fetal membranes and placenta during normal human pregnancy and parturition. Human Reproduction 12 2306-2312.

Thomson AJ, Telfer JF, Young A, Campbell S, Stewart CJR, Cameron IT et al. 1999 Leukocytes infiltrate the myometrium during human parturition: further evidence that labour is an inflammatory process. Human Reproduction 14 229-236.
Trittart HA, Mahnert W, Fleischhacker A, \& Adelwohrer N 1991 Potassium channels and modulating factors of channel functions in the human myometrium. Zeitschrift fur Kardiologie Supplementum $78029-33$.

Wray S 1990 The effects of metabolic inhibition on uterine metabolism and intracellular $\mathrm{pH}$ in the rat. Journal of Physiology $\mathbf{4 2 3}$ $411-423$.

Wray S 1993 Uterine contraction and physiological mechanisms of modulation. American Journal of Physiology 264 C1-C18.

Zyrianov VV, Sumovskaya AY \& Shostak AA 2003 Application of electron spin resonance for evaluation of the level of free radicals in the myometrium in full-term pregnancy with normal labour and uterine inertia. Journal of Biosciences 28 19-21.

Received 23 July 2004

First decision 7 September 2004

Revised manuscript received 18 March 2005

Accepted 6 May 2005 